[Vol. 106

\title{
A REMONSTRANCE FOR CONSCIENCE
}

\section{Harrop A. Freeman $\dagger$}

\author{
"You have been pleased to send up unto us a certain \\ prohibition or command that we should not receive or entertain \\ any of those people called Quakers because they are supposed \\ to be by some, seducers of the people. . . . \\ "[O] ur desire is not to offend one of his little ones. \\ . . . Therefore if any of these persons come in love unto us, \\ we cannot in conscience lay violent hands upon them, but \\ give them free egresse and regresse unto our Town, and \\ houses, as God shall persuade our consciences." 1
}

$†$ Professor of Law, Cornell University Law School; LL.B., 1930, Cornell University ; S.J.D., 1945, Cornell University.

1. The Flushing Remonstrance, Dec. 27, 1657. The States General of Holland had issued a Charter of Freedoms in 1640 offering to newly settled towns self-government and partial relief from taxes in order to attract settlers to New Netherlands. As a result, Governor Kieft granted a group of Englishmen a charter for Flushing in 1645 which provided the right "to have and enjoy liberty of conscience, according to the custom and manner of Holland, without molestation or disturbance. ." Kieft's successor, Governor Stuyvesant, a strict Calvinist, vacillated in limiting religious freedom. When flogging, deportation and property seizure failed to stop, among others, itinerant Quakers, from "preaching turbulently" against persecution, the Governor issued a placard proclamation fining any person who entertained a Quaker. Flushing viewed this as an interference with its charter rights and adopted the Remonstrance at a town meeting:

"Right Honorable,

"You have been pleased to send up unto us a certain prohibition or command that we should not receive or entertain any of those people called Quakers because they are supposed to be by some, seducers of the people. For our part we cannot condemn them in this case, neither can we stretch out our hands against them, to punish, banish or persecute them, for out of Christ God is a consuming fire, and it is a fearful thing to fall into the hands of the living God.

"We desire therefore in this case not to judge least we be judged, neither to condemn least we be condemned, but rather let every man stand and fall to his own Master. Wee are bounde by the Law to doe good unto all men, especially to those of the household of faith. And though for the present we seem to be unsensible of the law and the Law giver, yet when death and the Law assault us, if wee have our advocate to seeke, who shall plead for us in this case of conscience betwixt God and our own souls; the powers of this world can neither attack us, neither excuse us, for if God justifye who can condemn and if God condemn there is noe can justifye.

"And for those jealousies and suspicions which some have of them, that they are destructive unto Magistracy and Minsterye, that can not bee, for the magistrate hath the sword in his hand and the minister hath the sword in his hand, as witnesse those two great examples which all magistrates and ministers are to follow, Moses and Christ, whom God raised up maintained and defended against all the enemies both of flesh and spirit; and therefore that which is of God will stand, and that which is of man will come to nothing. And as the 
December 27, 1957 marked the 300th anniversary of the Flushing Remonstrance, the first American statement against governmental interference with religious conscience. It seems appropriate at this time to ask, "What of religious conscience in America today?" I center on the Flushing Remonstrarice rather than on any of the other great religious documents of the 17 th and 18 th centuries because later Remonstrances, particularly Madison's in Virginia, have already been honored as being the foundation of Church and State separation in

Lord hath taught Moses or the civil power to give an outward liberty in the state by the law written in his heart designed for the good of all, and can truly judge who is good, who is evil, who is true and who is false, and can pass definitive sentence of life or death against that man which rises up against the fundamental law of the States General; soe he hath made his ministers a savor of life unto life, and a savor of death unto death.

"The law of love, peace and liberty in the states extending to Jews, Turks, and Egyptians, as they are considered the sonnes of Adam, which is the glory of the outward state of Holland, soe love, peace and liberty, extending to all in Christ Jesus, condernns hatred, war and bondage. And because our Saviour saith it is impossible but that offenses will come, but woe unto him by whom they cometh, our desire is not to offend one of his little ones, in whatsoever form, name or title hee appears in, whether Presbyterian, Independent, Baptist or Quaker, but shall be glad to see anything of God in any of them, desiring to doe unto all men as wee desire all men should doe unto us, which is the true law both of Church and State; for our Saviour saith this is the law and the prophets.

"Therefore if any of these said persons come in love unto us, we cannot in conscience lay violent hands upon them, but give them free egresse and regreese unto our Town, and houses, as God shall persuade our consciences. And in this we are true subjects both of Church and State, for we are bounde by the law of God and man to doe good unto all men and evil to noe man. And this is according to the patent and charter of our Towne, given unto us in the name of the States General, Which we are not willing to infringe, and violate, but shall houlde to our patent and shall remaine, your humble subjects, the inhabitants of Vlishing."

The town clerk who prepared the document was imprisoned, and made to apologize before release. Among thirty-one signers, the sheriff who presented the document to the Governor and his council were imprisoned, fined and removed from office, while two magistrates were removed from office.

The sequel to the story occurred when John Bowne, who had joined the Friends (Quakers) as a result of these incidents, invited them to worship in his home. He was arrested, fined, put in solitary confinement and threatened with banishment, and on refusal to abstain from Quaker service, deported. The West India Company, although not approving Stuyvesant's action, continued the banishment, for "if you will not be subject to the laws and placards which are published we cannot suffer you in our jurisdiction." Bowne replied that "liberty was promised to us in a patent given [by you]. . . . For which of you being taken from your wife and family without cause, would be found from returning to them unless upon terms to act contrary to your conscience, and deny your faith and religion, and yet in this effect do you require of me but not less."

Finally Bowne was acquitted, the banishment revoked and he returned home; a message was sent to Stuyvesant by the company that "in all events people's conscience should not be forced by anyone but remain free in itself, as long as he is modest and behaves in a lawful manner and therefore does not disturb others or oppose the government." When the English took over the Colony's administration in 1664 they confirmed the Flushing liberty of conscience. In 1957 Bowne House was dedicated as an example of religious freedom. The fireplace bears the inscription: "In this room an oppressed people found sanctuary. . Here was born religious freedom and the American Way of Life." The story of Flushing is drawn from TREBOR, THE FLUSHING REMONSTRANCE (1957), and from original sources. 
America, ${ }^{2}$ yet do not primarily concern religious conscience. And although Maryland, Pennsylvania, and particularly Rhode Island under Roger Williams have been commended for their statements of liberty of conscience, these expressions were edicts of government and were often not applied to non-conformists. The Flushing declaration was made by ordinary citizens against government. It was based squarely on conscience and was intended, at frightful cost, to protect others. Here, in my judgment, lies the seed of freedom of conscience.

\section{Some Historical and Cultural Evidence}

In order to more accurately interpret the Constitution and the protection it affords conscience today, it might be helpful to briefly examine some evidence of recognition of conscience from the historical and cultural background of that document.

Pamphlets circulated in colonial America give us one indication of the early interest in conscience. Examples were "Bloudy Tenent of Persecution for Cause of Conscience Discussed" (Roger Williams, 1644); "No Cross, No Crown" and "The Great Cause of the Liberty of Conscience" (William Penn, 1650); "Rights of Conscience and Therefore Religious Opinions Not Cognizable by Law" (John Leland, 1780) $:^{3}$

"It is not too much to say that whatever evidence exists supports the view that when the Constitutional Convention convened in Philadelphia in 1787 the overwhelming majority of Americans accepted the proposition that religion was a personal, non-political matter and concurred with Paine's statement in Common Sense that: 'As to religion, I hold it to be the indispensable duty of government to protect all conscientious professors thereof; and I know of no other business which government hath to do therewith." " 4

2. Everson v. Board of Educ., 330 U.S. 1, 8-12 (1946); Davis v. Beason, 133 U.S. 333. 342 (1890); Reynolds v. United States, 98 U.S. 145, 164 (1878); Konvirz, FundaMenTAL LiberTies OF A FREE PEOPLE c. 4 (1957).

3. See generally Blau, Cornerstone of Reuigious Frejoom in America (1949); Cobb, The RIse of Religious Liberty in America (1902) ; Humphrey, NationalISM AND RELIGION IN AMERICA (1942); Konvitz, op. cit. supra note 2; PFEFFer, Church, State and Friedom (1953); Stokes, Church and State in the United States (1950); SweEt, Reitgion in Colonial America (1946); SweEt, The Story of RELIGION IN AMERICA (1939). It would be incorrect to infer that freedom of conscience was anything like an accepted church position in our early history. The community of Church and State and the weapon of heresy were the established European pattern, both Catholic and reformed. Any emphasis on conscience was carried by the dissident sects: Annabaptists, Doukhabors, Mennonites, Quakers, and others. This pattern was not substantially changed in seventeenth-century America.

4. Pfeffer, No Law Respecting an Establishment of Religion, 2 Bufralo L. REv. 225, 231 (1952). 
Many colonial laws recognized the rights of conscience, typical of these being the militia laws. Between 1600 and 1775 the colonies enacted over 600 militia laws. Beginning with Rhode Island in 1673 these regularly embodied clauses exempting conscientious objectors, either absolutely or conditionally. ${ }^{5}$ Because of conscience Pennsylvania had only a voluntary militia law and the Quakers gave up control of government to avoid forcing anyone into military service. ${ }^{6}$ General recognition of the importance of conscience at the time of the Revolution is illustrated by the resolution of the Continental Congress, July 18,1775 :

"As there are some people, who, from religious principles, cannot bear arms in any case, this Congress intend no violence to their consciences, but earnestly recommend it to them, to contribute liberally in this time of universal calamity, to the relief of their distressed brethren in the several colonies, and to do all other services to their oppressed country, which they can consistently with their religious principles." 7

An examination of the constitutions of the early states shows that each had a protection of conscience clause. ${ }^{8}$ The distinction between true religious conscience and acts of licentiousness in the name of conscience was fully understood at the time, and the necessity of preventing the second did not detract from the protection of the former. ${ }^{9}$

5. Setective Service System, Background of Selective Service (Spec. Monographs 1947, 1950); Russell, Development of Conscientions Objector Recognition in the United States, 20 GEO. WASH. L. REV. 409 (1952).

6. Ibid.

7. JOURNALS OF CONGRESS 159 (1800).

8. PA. Consr. art. $1, \S 3$ : "All men have a natural and indefeasible right to worship Almighty God according to the dictates of their own consciences . . no human authority can, in any case whatever, control or interfere with the rights of conscience. ..."

N.C. Const. art. 1, § 26: Same words except "should" for "can" and "unalienable" for "indefeasible."

VT. Const. art. 3: "according to the dictates of their own consciences," and "no authority can ... in any case interfere with ... the rights of conscience. ..."

MD. Consr. art. 36: "protection in their religious liberty . . . for his religious practices. ..."

S. C. Consr. art. 4 : same expression as in the first amendment.

R.I. Const. art. 3: "free to worship God according to the dictates of his own conscience."

N.H. CoNst. art 4 : "rights of conscience."

N.J. ConsT. art. 1, \& 3: "agreeable to the Dictates of his own Conscience."

MAss. Const. art. II: "agreeable to the dictates of his own conscience."

DEL. CoNST. art. 1, $\$ 1$ : "no power shall ... interfere with, or in any manner control the rights of conscience. ..."

GA. CoNST. art 1, \$2-113: "right of liberty of conscience."

VA. Const. art. 1, \$ 16: "according to the dictates of conscience."

9. See the reference in Davis v. Beason, 133 U.S. 333, 348 (1890), that the New York Constitution of 1777 contained the following clause: "Provided, That the liberty of conscience, hereby granted, shall not be so construed as to excuse acts of licentious- 
Religion was not mentioned in the original Constitution because it was thought that the federal government should have no control over the subject and that only those matters delegated to the central government were within its powers. ${ }^{10}$ When the Constitution was ratified by the states, New Hampshire requested an amendment that "Congress shall make no laws touching religion or to infringe the rights of conscience." 11 Virginia's ratification declared "that among other essential rights, the liberty of conscience . . . cannot be cancelled, abridged, restrained or modified by any authority of the United States" and recommended an amendment. ${ }^{12}$ North Carolina made an identical declaration ${ }^{13}$ and Rhode Island's was similar: "all men have an equal, natural, and unalienable right to the free exercise of religion, according to the dictates of conscience." 14 New York employed the same words. ${ }^{18}$ Maryland and Pennsylvania proposed amendments but did not send them to Congress on the then popular assumption that the federal government had no delegated power which could affect religion and that an express reservation was unnecessary; the proposal read: "the rights of conscience should be held inviolable." 16 It is impossible to review all the communications in this regard; they were all substantially the same as those set forth above.

Neither do space limitations permit us to review the attitudes of all the Congressmen who adopted the first amendment. But we can examine the outside statements of Madison, deemed most responsible for the amendment's adoption, ${ }^{17}$ and some of the comments of others within Congress during the adoption. Madison was the chief sponsor of Jefferson's "Bill for Establishing Religious Freedom in Virginia," and declared that rights of conscience and religious freedom were "natural rights of mankind." To induce the passage of this bill, Madison issued his famous Memorial and Remonstrances, which states in part:

"The Religion then of every man must be left to the conviction and conscience of every man; and it is the right of every man to ness," and that similar provisions appeared in the constitutions of California, Colorado, Connecticut, Florida, Georgia, Illinois, Maryland, Minnesota, Mississippi, Missouri, Nevada and South Carolina.

10. 3 Elitor, Debates on the Feneral Constifution 93, 204 (1901). There is some evidence that a "conscience" protection clause was submitted. 3 FARRAND, RECORDS OF THE FEDERAL CONVENTION OF 1787, at 290 (1937).

11. 1 ElLior, op. cit. supra note 10 , at 326 .

12. 1 id. at $327 ; 3 i d$. at 659 .

13. 4 id. at $244,251$.

14. 1 id. at 334 .

15. 1 id. at 328 .

16. Maryland's did not use "conscience."

17. See Everson v. Board of Educ., 330 U.S. 1, 34 (1946). 
exercise it as these may dictate. This right is in its nature an unalienable right. . . . [A]1l men are to be considered as entering into Society on equal conditions; as relinquishing no more, and therefore retaining no less, one than another, of their natural rights. Above all are they to be considered as retaining an equal title to the free exercise of Religion according to the dictates of conscience." 18

On June 8, 1789, Madison introduced the first proposed amendments to the Federal Constitution. The fourth and fifth of these read:

"Fourthly, that in Article 1st, section 9, between clauses 3 and 4, be inserted these clauses, to wit: The civil rights of none shall be abridged on account of religious belief or worship, nor shall any national religion be established, nor shall the full and equal rights of conscience be in any manner, or on any pretext, infringed. . . That in Article 1st, section 10, between clauses 1 and 2, be inserted this clause, to wit: No State shall violate the equal rights of conscience, or the freedom of the press, or the trial by jury in criminal cases." 19

On June 8, 1879 this draft was referred to the Committee of the Whole and on July 21 st was transferred to a committee of eleven members, one from each state, with Mr. Madison representing Virginia. ${ }^{20}$ The Committee of Eleven on August 15th referred back to the House the amendment, "nor shall the equal rights of conscience be infringed." 21 The Annals of Congress are unusually complete in the report of the discussion. ${ }^{22} \mathrm{Mr}$. Carroll believed that "conscience . . . will little bear the gentlest touch of governmental hand." Mr. Madison joined in his views. Mr. Huntington wanted "the amendment... to secure the rights of conscience." Mr. Livermore offered an amendment to prevent "laws . . . infringing the rights of conscience" and his motion was passed, thirty-one for and twenty against. ${ }^{23}$ At a later point in the debate Mr. Madison again insisted on protection of conscience. $^{24}$

On August 17th the House turned to what is now the second amendment (right to keep arms); the amendment contained a provision: "but no person religiously scrupulous shall be compelled to bear arms." ${ }^{25} \mathrm{Mr}$. Jackson and Mr. Smith proposed that conscientious

18. 2 Writings of James Madison 183-91 (1901).

19. 1 Annals of Cong. 434-35 (1834).

20. $I d$. at 450,660 .

21. Id. at 729 .

22. Id. at 729-31.

23. $I d$. at 730 .

24. Id. at 746 .

25. Id. at 749 . 
objectors should provide a substitute, but the general sentiment, including that of Mr. Sherman, Mr. Vining and Mr. Stone, was strongly against this as itself violating conscience. ${ }^{26}$ Finally, Mr. Benson proposed that the clause protecting the "religiously scrupulous" be stricken. The motion to strike the clause was lost. ${ }^{27}$.

On the same day the fifth proposition that "no State shall infringe the equal rights of conscience" was considered. "Mr. Madison conceived this to be the most valuable amendment in the whole list. . . . Mr. Livermore had no great objection to the sentiment, but he thought it not well expressed" and merely transposed clauses. "This transposition being agreed to . . . the clause was adopted." 28

August 20,1789, the House resumed consideration of the fourth (conscience) amendment, which on motion of Mr. Ames read: "Congress shall make no law establishing religion, or to prevent the free exercise thereof, or to infringe the rights of conscience." 29 The rightto-bear-arms amendment was briefly considered and the "religiously scrupulous" exemption was left in, with the added words "in person." 80 No further change of any of these clauses was ever discussed in Congress. It appears that later revisions were revisions only of language which all agreed carried out the above intendments.

Thus.all the amendments were adopted in the House on August 24th, and at that time what is now the first amendment read in part: "Congress shall make no law establishing religion or prohibiting the free exercise thereof, nor shall the rights of conscience be infringed." No record was made of the Senate debates discussing this amendment and no light has been thrown thereon by examination of the private papers of the Senators or of current newspapers or magazines. The lack of any such account of debate regarding the amendment, as compared to some other provisions, tends to show that the chief concern of the Senate was as to form rather than disagreement with content. The short period of time during which the House proposal was before the Senate, and the fact that the Senate change of words was accepted by the conference committee and later by the House without debate tends to show that all believed the present first amendment language to reflect these earlier sentiments. ${ }^{31}$ Soon after the adoption of the first amendment, Aedamus Burke noted in Congress that requiring a 
conscientious objector to pay a fee for exemption was "contrary to the Constitution" and the exemption of those "conscientiously scrupulous of bearing arms" was referred to as a recognized principle in the first congressional debates on the militia bill. Jefferson in 1801 (Notes on Virginia) explained the theory of government as being that the state had control only over such "natural rights as we have submitted to them," adding: "The rights of conscience we never submitted, we could not submit. We are answerable for them to our God." The first case involving religion to reach the Supreme Court called forth a comment on Virginia's recognition of "dictates of conscience" to which was added that, "The revolution might justly take away the public patronage, the exclusive cure of souls, and the compulsive taxation for the support of the church. Beyond these, we are not prepared to admit the justice or the authority of the exercise of legislation." 32

It would appear from the above that the first amendment was intended to protect freedom of conscience and that conscientious objection to war was a well recognized, time honored expression of such conscience.

\section{Conscience in Our Cultural Heritage}

If such be the place of conscience in our constitutional and legal history, to what degree is the same true in our cultural heritage? Our civilization is surely grounded in Judeo-Christian ethics and GraecoRoman thought, and traces itself through the Reformation and the English parliamentary common-law concepts of the rights of man. A quick review of the pattern of the Old and New Testaments will show that the Judeo-Christian religion has always maintained the duty to obey God speaking through conscience as superior to any civil law. The first three chapters of Genesis tell the story of Adam and Evewhat occurs when man violates the will of God. In the first two chapters of Exodus is the story of how Moses' parents broke the law requiring the drowning of every male baby by hiding him in the bullrushes. Jesus' parents broke a law in fleeing with him to Egypt (Matt. 2:12, Luke 2:39). The breaches of law by Jesus are well known: teaching publicly on the Sabbath (John 7:1, Matt. 4:13, Luke 4:16); healing on the Sabbath (John $5: 1$, Matt. $12: 9$, Mark $3: 1$, Luke 6:6, John 10:1, Matt. 19:12, Mark 10:1, Luke $13: 10$ ); plucking and eating corn (Matt. 12:1, Mark 2:23, Luke 6:1) ; not washing hands (Matt. 15:1, Mark $7: 1$ ). So also are Jesus' words: "Render 
unto Caesar the things that are Caesar's and unto God the things that are God's" (Matt. 22:21, Mark 12:17, Luke 20:25). Two of the first acts of the disciples were breaches of the law, producing arrests of Peter, John and Stephen and the words of Peter, "Whether it be right in the sight of God to harken unto you more than unto God, judge ye" (Acts 5,6). Without spending time to trace this same view through the many years of Catholic and Reformation thought, we may properly refer to the theology of Thomas Aquinas at the midpoint and to a recent Catholic and Protestant restatement.

We may also properly retrace our steps to see the doctrine out of which this right to civil disobedience arises. It is fully recognized that the growing central ethic of the Judeo-Christian religions (and the same is true of most non-Christian religions) is the concept of love or agapé, even of enemies, as the acceptable worship of God and the fulfilment of self. ${ }^{34}$ This is the ethic which, when carried out in practice, is known as pacifism or conscientious objection. Historians concede that the Christian Church was pacifist for the first three centuries, that a strong pacifist tendency marks the good Christian at all times, and that the most recent statements of the Christian Church recognize this ethic. ${ }^{35}$

But, reliance on conscience never confined itself solely to the religious portion of our culture. It spilled over into our literature, philosophy and political theory. We cannot possibly trace it in all this

33. Sr. Thomas Aquinas, The Sumra Theologica question XCVI: "Laws of this kind [unjust] must nowise be observed, because as stated in Acts, V. 29 , we ought to obey God rather than man"; Conway, The Question Box 186 (1929): "The Catholic Church teaches that no man's allegiance to the State is absolute, but that it is always limited by conscience and the law of God.

34. The Judaeic development comes from the period of the great prophets: Amos, Hosea, Micah, Isaiah, Jeremiah, Ezekiel and Second Ezekiel (760-535 B.C.), eventuating in the Hebrew call to worship: ". . . thou shalt love the Lord thy God with all thy heart and all thy soul and all thy mind and all thy strength; and thou shalt love thy neighbor as thyself." This will be recognized as the two great commandments restated by Jesus as the essence of religion. See further Amos, chapters 1-2; Isaiah, chapters 40-49; Ezekiel, chapters 23-33; Micah, chapter 6; Hosea, chapter 11. ARCHER, Faiths Men Live By (1934); BurTi, Man SeEks The Divine (1957); Kohler, THE Foundations of Jewish ETHICs (1929); MCGIFFert, A History of Cirristian Thought (1932); SNeate, Evolution of EThics (1927).

35. Cadoux, The Early Christian Atritude to War (1940); Cuningeim, FREEDON's HOLY LIGHT (1955), reviewed in 11 Sw. L.J. 169 (1957); FREEMAN, QUakers and PEAcE (1948); Harding, a ReViving Natural Law (1955). The Assembly of the World Council of Churches in Amsterdam in 1948 and Chicago in 1956 condemned "any attempt to impair the freedom of men to obey God and to act according to conscience" and recognized an absolute witness against war as a Christian witness. This was reiterated by the Council of Churches of Christ in America, at St. Louis, December 4, 1957. One of the keenest observers of the history of religious thought has just pointed out that the direction in which the religious ethic and action is most likely to move in this century will come from Gandhian ahimsa (love) and satyagraha (soul force or civil disobedience) and from psychotherapy's development of the internal unity or conscience of the individual. BuRry, op. cit. supra note 34 , at 481-524. 
area, but we may refer to a few key figures recognized as having a deciding effect on American life and institutions. The Greek period is typified by Homer (850 B.C.), Sophocles (496-406 B.C.), Socrates (469-399 B.C.) and Aristotle (384-322 B.C.). Homer's Iliad is an indictment of the doctrine of naked force which destroys the inner self and makes men into things. Sophocles in Antigone honors a sister who follows her conscience to bury her brother in violation of law. Socrates in his Apology bases his defense to law violation on his higher obligation to truth and conscience, and Aristotle's political and philosophical thought is most often summarized in his words: "what is right lies in a man's own breast. Trust thyself" (Ethics). This thread was carried through Roman thought by. men like Cicero"We cannot be freed from its [conscience] obligations by senate or people" ( $D e$ Re Publica)..$^{\text {s6 }}$

Perhaps no two writers in our civilization have had more influence on American constitutional thought than John Locke, often referred to at the Constitutional Convention, and John Milton, from whom Jefferson and the Supreme Court borrowed almost verbatim the basic first amendment theory of "truth in the market place." Milton it was who said in 1644:

"Give me the liberty to know, to utter and to argue freely, according to conscience, above all liberties. . . . And though all the winds of doctrine were let loose to play upon the earth, so Truth be in the field, we do injuriously by licensing and prohibiting, to misdoubt her strength. Let her and falsehood grapple. Who ever knew Truth put to the worse in a free and open encounter?"'

And John Locke, speaking a few years later in Concerning Toleration:

" $[I] \mathrm{t}$ is also evident what liberty remains to men in reference to their eternal salvation, and that is, that every one should do what he in his conscience is persuaded to be acceptable to the Almighty. . . For obedience is due, in the first place, to God, and afterwards to the laws."

Touch where you will American thought and you find this same emphasis on conscience. We have already referred to the writings of Williams, Penn, Paine, Jefferson and others. The most frequently quoted phrase in George Washington's copy-book was "labour to keep alive in your breast that little spark of celestial fire,-conscience." And

36. See note 33 supra. See also Corwin, The "Higher Laz" Background of American Constitutional Lazw, 42 HARv. L. REv. 149 (1928); Hall, REAdngs IN JURISPRUDENCE, C. 1 (1938). 
the writings of Emerson, Parker, Phillips, Thoreau, containing these same emphases, were everyday reading one hundred years ago. More recently, witness the place of conscience in the four freedoms advocated by President Roosevelt in the midst of World War II. Article 18 of the Universal Declaration of Human Rights guarantees "freedom of thought, conscience and religion . . . to manifest his religion or belief in teaching, practice, worship and observance." And at Nuremberg men were found guilty of crimes for "persecution . . . of pacifist groups, including religious movements dedicated to pacifism" though they acted under "orders of government."

Nearly every writer who has described our culture has diagnosed the crisis of our age and that which caused the fall of other civilizations as the rise of militarism and the decline of the internal moral sense or conscience. $^{37}$ And what is the psychiatric description of a mature individual and a sane society? I believe we can use the words of Erich Fromm as typical:

"The mentally healthy person is the productive and unalienated person; the person who relates himself to the world lovingly, and who uses his reason to grasp reality objectively; who experiences himself as a unique individual entity, and at the same time feels one with his fellow man; who is not subject to irrational authority, and accepts willingly the rational authority of conscience and reason; who is in the process of being born as long as he is alive and considers the gift of life the most precious chance he has.

"A sane society is one. . . where acting according to one's conscience is looked upon as a fundamental and necessary quality. . . " 38

So much, then, for this brief historical and cultural survey of conscience.

\section{The First Amendment and Its Present Interpretation}

What is the legal protection afforded conscience today? The ultimate form of the first amendment is well known: "Congress shall make no law respecting an establishment of religion, or prohibiting the free exercise thereof." Certain areas reflecting the "establishment"

37. Sorokin, The Crisis of OUr Age (1946); Sorokin, Soctal and Cultural Dynamics (1957); TOYNBEe, A Study of History (1949); TOYNBE, WAR AND Civilization (1950).

38. Fromar, The Sane Society 275-76 (1955). See also May, Man's Search for Himself (1953); MenNinger, Love Against Hate (1942); Overstreet, The Mature Mind (1949). 
as opposed to the "free exercise" clause are regarded as well settled by Supreme Court decisions. Thus the Court has repeatedly erected "a wall of separation between church and state." 39 All the Justices make this an "absolute" in preventing establishment of any religion or aid to less than all religions, ${ }^{40}$ although some question remains whether the Court has not itself "established" a state religion that "we are a Christian people... whose institutions presuppose a Supreme Being." "41 A minority of the Justices would allow for no breach of the wall of separation, unless it be for minor customs like offering public prayer. A majority would make the separation relative to allow cooperation with religion generally. ${ }^{42}$ So also the Court has left churches free from state control in matters of church government ${ }^{43}$ and in faith, doctrine and belief, for "the law knows no heresy, and is committed to the support of no dogma, the establishment of no sect." 44 Finally, all seem to agree that government need not be irreligious but may participate in certain symbolic or customary religious acts. ${ }^{45}$

The fourteenth amendment applies all or part of the first amendment protections as restrictions on the states. The majority, speaking originally through Justice Cardozo and later Justice Frankfurter, distinguish fundamental liberties (free speech, free press, free assembly, "free exercise of religion," and right to counsel) from those of inferior status as "implicit in the concept of ordered liberty" and therefore em-

39. Zorach v. Clauson, 343 U.S. 306 (1952); Illinois ex rel. McCollum v. Board of Educ., 333 U.S. 203 (1948); Everson v. Board of Educ., 330 U.S. 1 (1947); Reynolds v. United States, 98 U.S. 145 (1878).

40. Ibid.

41. Zorach v. Clauson, 343 U.S. 306 (1952); United States v. MacIntosh, 283 U.S. 605 (1930) ; Church of the Holy Trinity v. United States, 143 U.S. 457 (1892). See 68 STaT. 249 (1954), 36 U.S.C. \& 172 (Supp. IV, 1957). Note how this "state religion" has become the test in the Selective Service Law of 1948, 62 Star. 609 (1948), 50 U.S.C. APP. $\$ 456$ (j) (1952) and also how it has been applied as a common-law doctrine in Washington Ethical Soc'y v. District of Columbia, 249 F.2d 127 (D.C. Cir. 1957).

42. Cases which the minority believed improperly breached the wall of separation included Doremus v. Board of Educ., 342 U.S. 429 (1952) (reading from the Old Testament and offering the Lord's Prayer without comment as non-sectarian); Zorach v. Clauson, supra note 41 (a "released time" case, which they felt used the compulsory school machinery to channel pupils into sectarian classes as much as though school buildings were used); Everson v. Board of Educ., 330 U.S. 1 (1947) (transportation of children to religious as well as public schools); Cochran v. Louisjana State Bd. of Educ., 281 U.S. 370 (1930) (state purchase of non-religious textbooks for both public and religious schools).

43. Kedroff v. St. Nicholas Cathedral, 344 U.S. 94 (1952) ; Watson v. Jones, 80 U.S. 679 (1871); Melish v. Holy Trinity, 301 N.Y. 679, 95 N.E.2d 43 (1950), cert. denied, 340 U.S. 935 (1951). See Note, 67 HARv. L. Rev. 91, 92 (1953).

44. United States v. Ballard, 322 U.S. 78, 86 (1944); Note, 67 Harv. L. Rev. 91, 92 (1953).

45. Zorach v. Clauson, 343 U.S. 306, 312-13 (1952); Paulsen, Preferment of Religions Institutions in Tax and Labor Legislation, 14 LAW \& CoNTEMP. ProB. 144 (1949); Stimson, Exemption of Property From Taxation in the United Statcs, 18 MINN. L. REV. 411 (1934). 
bodied in the fourteenth amendment. ${ }^{48}$ The minority, for which Justice Black often speaks, views the fourteenth amendment as intended "to extend to all people of the nation the complete protection of the Bill of Rights." 47 For our purposes the two positions may result in little difference except that in state cases the Court may find it easier to consider "free exercise of religion," like free speech, press and assembly, as one of the democratic rights contributing to "free thought in the market-place." 48 It seems that this is precisely what the Court has done in the many cases protecting Jehovah's Witnesses and others in their right of assembly, pamphleteering or other unorthodox methods of seeking converts. ${ }^{49}$ But if this were the only protection in the "free exercise" clause it would amount to rewriting "free exercise of religion" to mean "free discussion of religious belief."

It would thus seem that the concept of "no establishment" in the first amendment has been adequately defined, though questions may still arise as to factual application. The area which imperatively demands the Supreme Court to speak relates to the other clause, "Congress shall make no law . . . prohibiting the free exercise" of religion. And more specifically, we need to have defined whether religion embraces religious conscience and whether acts done under the direction of conscience are protected as free exercise of religion.

\section{Exercise of Religious Conscience-The Undetermined First Amendment Subject}

Not too frequently has the Supreme Court used the term "conscience" in its opinions. When it has, though the connotations have not always been spelled out and are not always the same, there has invariably been the assumption that conscience is the inner guide determining what is morally right and wrong and what is demanded of the individual by his god or religion. It has been said that "the struggle for religious liberty has through the centuries been an effort to accommodate the demands of the State to the conscience of the individual"

46. Palko v. Connecticut, 302 U.S. 319 (1937) ; Adamson v. California, 332 U.S. 46 (1947); Konvitz, THE Constitution aND CrvL RIGHTs c. 3 (1947); Fairman, Does the Fourteenth Amendment Incorporate the Bill of Rights?, 2 STAN. L. REv. 5 (1949).

47. Adamson v. California, supra note 46, at 68 (dissenting opinion); see also Crosskey, Charles Fairman, "Legislative History," and the Constitutional Limitations on State Authority, 22 U. CHI. L. REv. 1 (1954); Fairman, A Reply to Professor Crosskey, 22 U. CHI. L. REV. 144 (1954).

48. United States v. Ballard, 322 U.S. 78 (1944); Board of Educ. v. Barnette, 319 U.S. 624 (1943).

49. Taylor v. Mississippi, 319 U.S. 583 (1943) ; Douglas v. City of Jeanette, 319 U.S. 157 (1943); Martin v. City of Struthers, 319 U.S. 141 (1943); Murdock v. Pennsylvania, 319 U.S. 105 (1943); Cantwell v. Connecticut, 310 U.S. 296 (1940); Dumbauld, The Bill of Rights 115-39 (1957). 
and that the "Bill of Rights recognizes that in the domain of conscience there is a moral power higher than the State." so The Court has defined the term "religion" and the intendment of the first amendment as follows:

'The term 'religion' has reference to one's views of his relations to his Creator, and to the obligations they_impose of reverence for his being and character, and of obedience to his will. . . . The first amendment . . . was intended to allow every one . . . to entertain such notions respecting his relations to his Maker and the duties they impose as may be approved by his judgment and conscience, and to exhibit his sentiments in such form of worship as he may think proper, not injurious to the equal rights of others. . . ." 51

It has acknowledged "the theory and practice of our government in relation to freedom of conscience." 52 Some Justices have admitted that the first amendment was grounded in the "pronouncement that freedom of conscience and religion are inherent rights of the individual" and that governmental action may be "a violation of rights both of conscience and of natural equality." 53 So also "conscience" has been used interchangeably with "religion" in speaking of the first amend-

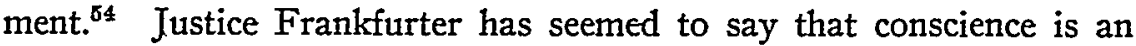
inner rational or irrational opinion, of a high order but perhaps erroneous, which one may have to (and can) abandon in the face of jail or majority opinion..$^{55} \mathrm{He}$ apparently views freedom of religion as restricted to dogma and worship rather than as protecting acts dictated by conscience.

The fullest treatment of "conscience" is probably that in the dissent of Justices Hughes, Holmes, Brandeis, and Stone in United States

50. Girourard v. United States, 328 U.S. 61, 68 (1946); MacIntosh v. United States, 283 U.S. 605 (1937).

51. Davis v. Beason, 133 U.S. 333, 342 (1890).

52. Schneiderman v. United States, 320 U.S. 118, 135 (1943) ; Reynolds v. United States, 98 U.S. 145, 164 (1878).

53. Justice Rutledge in Everson v. Board of Educ., 330 U.S. 1, 35-38 (1947) (dissenting opinion).

54. Justices Rutledge, Black, Douglas, Murphy, and Jackson in Thomas v. Collins, 323 U.S. 516, 531 (1945).

55. See United States v. Nugent, 346 U.S. 1, 12-13 (1953); “. . . So long as no inroads are made upon the actual exercise of religion by the minority, to deny the political power of the majority to enact laws concerned with civil matters, simply because they may offend the consciences of a minority, really means that the consciences of a minority are more sacred and more enshrined in the Constitution than the consciences of a majority." Board of Educ. v. Barnette, 319 U.S. 624, 646 (1943) (dissenting opinion); cf. Justice Frankfurter's expression "matters sacred to conscience" in Board of Educ. v. Barnette, supra at 653: "The Constitutional protection of religious freedom terminated disabilities, it did not create new privileges. It gave religious equality, not civil immunity. Its essence is freedom from conformity to religious dogma, not freedom from conformity to law because of religious dogma." 
v. MacIntosh, ${ }^{56}$ in which the majority held valid an interpretation of an immigrant's oath of citizenship to require the bearing of arms. The case was later overruled and the dissent takes on added significance since subsequent decisions have referred to it as the present majority position. ${ }^{57}$ Its reasoning may be summarized as follows: granted that the immigrant's oath is voluntary and that there is no constitutional right to citizenship, the oath is the same as that administered to public officers who are citizens, and thus indirectly a constitutional rather than a mere statutory interpretation question is presented as to whether conscientious objectors can be required to agree to bear arms; conscience is protected by the first amendment; the very essence of conscience (and religion) is recognition of duties to God superior to those to the state; federal legislation granting exemption to conscientious objectors is not a matter of legislative grace but "indicative of the actual operation of the principles of the Constitution."

But the Supreme Court has never squarely faced the problem of the extent of protection granted to conscientious objection to war by the Constitution. The MacIntosh case held and Hamilton v. Regents of the University of California ${ }^{58}$ stated by way of dictum that conscientious objection to war is a matter of legislative grace and not a constitutional right. Both cases involved what the Court treated as a privilege to which the state could attach conditions-in Hamilton the opportunity to attend a tuition-free college only if the student took ROTC training. But this proves little as to the constitutional issue, for both cases were decided on statutory grounds. The Hamilton case was later distinguished in Board of Education v. Barnette ${ }^{59}$ which relieved those religiously opposed from saluting the flag, on the ground that one involved voluntary and the other coerced action.

It has been suggested that the words in both cases may be taken as merely statements of an historical fact-that Congress has in practice exempted conscientious objectors. This seems to me to disregard the words "not from the constitution" in the MacIntosh case. However, there is some indication in the Court's overruling of MacIntosh that it also cancelled any implication that the right of conscientious objectors is statutory only. For the Court reviews the history of conscience, treats it as the producer of the first amendment and concludes:

56. 283 U.S. 605, 627 (1931) (dissenting opinion).

57. See Girourard v. United States, 328 U.S. 61, 63-70 (1946); Schneiderman v. United States, 320 U.S. 118 (1943).

58. 293 U.S. 245 (1934). It is interesting to note that the first attack on conscientious objector treatment was made on the "establishment" clause. Selective Draft Law Cases, 245 U.S. 366 (1918).

59. 319 U.S. 624 (1943). 
"Over the years, Congress has meticulously respected that tradition and even in time of war has sought to accommodate the nilitary requirement to the religious scruples of the individual." ${ }^{60}$ This is the same constitutional history that led the four dissenters in MacIntosh to assume that the right was constitutional:

"This Federal legislation is indicative of the actual operation of the principles of the Constitution, that a person with conscientious or religious scruples need not bear arms, although as a member of society, he may be obliged to render services of a non-combatant nature." 61

The lower federal courts have fairly consistently followed the dictum that the right is merely statutory. ${ }^{62}$ Some current writers accept this view ${ }^{63}$ and others reject it. ${ }^{64}$ Since cases involving federal action alleged to violate conscience come to the Supreme Court by permission, and since objection to state action on the grounds of conscience is infrequent, the Court has been able to avoid a direct consideration of the issue, as it has of the protection of conscience generally. ${ }^{65}$

Reference is often made to the considerable number of cases in the past fifteen years in which the Supreme Court has protected con-

60. Girourard v. United States, 328 U.S. 61,69 (1946).

61. Justices Hughes, Holmes, Brandeis, and Stone, United States v. MacIntosh, 283 U.S. 605, 633 (1931) (dissenting opinion).

62. George v. United States, 196 F.2d 445 (9th Cir. 1952); United States v. Kime, 188 F.2d 677 (7th Cir. 1951); Michener v. United States, 184 F.2d 712 (10th Cir. 1950) ; Richter v. United States, 181 F.2d 591 (9th Cir. 1950).

63. Cornele, The Consctentious Objector and the Law (1943); Cornell, Exemption From the Draft: $A$ Study in Civil Liberties, 56 YALE L.J. 258 (1947).

64. Freeman, The Constitutionality of Peacetime Conscription, 31 VA. L. Rev. 40 (1944). Although KoNvITz, FUNDAMENTAL LIBERTIES OF A FREE PEOPLE 48 (1957), states that the matter is one of legislative grace, it is my understanding that he was summarizing the case law and not discussing the proper constitutional theory.

65. Clark v. United States, 236 F.2d 13 (9th Cir.), cert. denied, 352 U.S. 882 (1956) (a Unitarian challenging the Supreme Being clause); Davidson v. United States, 218 F.2d 609 (9th Cir. 1954), remanded, 349 U.S. 918 (1955), reaff'd, 225 F.2d 836 (1955), cert. denied, 350 U.S. 887 (1956) (attempt to question the Supreme Being clause); George v. United States, 196 F.2d 445 (9th 'Cir.), cert. denied, 344 U.S. 843 (1952) (refusal to report for induction and failure to file classification questionnaire on grounds of conscience); United States v. Kime, 188 F.2d 677 (7th Cir. 1951), cert. denied, 342 U.S. 823 (1952) (failing to carry registration card for conscience reasons); Richter v. United States, 181 F.2d 591 (9th Cir.), cert. denied, 340 U.S. 892 (1950) (refusal to register on ground draft act violated first amendment); Cannon v. United States, 181 F.2d 354 (9th Cir.), cert. denied, 340 U.S. 892 (1950) (refusal to register on ground draft act violated first amendment); Frantz v. United States, 180 F.2d 711 (7th Cir. 1950), cert. denicd, 339 U.S. 963 (1951) (refusal of Quakers to complete Selective Service forms, though notifying draft boards, as military action contrary to conscience); Gara v. United States, 178 F.2d 38 (6th Cir. 1949), aff'd by an equally divided Coutr, 340 U.S. 857 (1950) (dean of students encouraging student to obey his conscience in not registering); Warren v. United States, 177 F.2d 596 (10th Cir. 1949), cert. denied, 338 U.S. 947 (1950) (father, a religious objector, counselling son not to register for draft; son registered; father convicted of counselling draft violation, over defense of conscience); United States v. Atherton; 176 F.2d 835 (9th Cir. 1949), cert. denied, 338 U.S. 938 (1950) (refusing to remain in C.P.S. camp). 
scientious objectors. But none of these cases involve issues of conscience. In all the Court has guaranteed only due process and procedural protection. ${ }^{66}$ Such fair procedure must be granted a person whether the right he is seeking to protect comes from the legislature, the court or the Constitution. In this process of protection the Court has required a procedure for review of local board classification, a record containing facts to support the decision, a fair resume of the unfavorable evidence in the Government's file, and compliance with the statute and regulations. On the other hand, where a Quaker's conscience would not permit him to utilize procedure he considered military, the Court refused to grant certiorari to determine whether he was relieved by conscience from the necessity of exhausting administrative remedies, even though the Third Circuit had requested the case be argued twice and finally decided it four to three. ${ }^{67}$

Perhaps the most difficult issue in the realm of conscience or religion is whether the fact that a person does an act under the compulsion of religious conscience is or is not a defense to a law which makes such act illegal. Reynolds $v$. United States, ${ }^{68}$ the first case to consider the free exercise clause, held that a Mormon's religious belief in polygamy was no defense to criminal prosecution for bigamy. The core of the argument was:

"Congress was deprived of all legislative power over mere opinion, but was left free to reach actions which were violations of social duties or subversive of good order. . . . Can a man excuse his practices . . . [which violate laws] because of his religious be-

66. Gonzales v. United States, 348 U.S. 407 (1955); Simmons v. United States, 348 U.S. 397 (1955); Sicurella v. United States, 348 U.S. 385 (1955); Witmer v. United States, 348 U.S. 375 (1955) (The board must show a basis in fact to defeat the registrant's statement of belief ; proof that a person will participate in a theocratic war is insufficient to defeat his sincerity of conscience; he must be given a copy of any unfavorable FBI report.); Dickinson v. United States, 346 U.S. 389 (1953) (There must be affirmative evidence in the record to support the local board's determination, otherwise its decision will be upset.); United States v. Nugent, 346 U.S. 1 (1953) (dictum) (A conscientious objector must be furnished with a fair resumé of any adverse evidence.) ; Estep v. United States, 327 U.S. 114 (1945) (Where the classification process was complete and the order was unlawful it could be challenged as a defense in a criminal prosecution; the statute did not by using the word "final" remove an erroneous order from review.). See the many lower court cases discussed in Note, 50 Nw. U.L. Rev. 660 (1955) ; see also Cox v. United States, 332 U.S. 442 (1947) ; Sunal v. Large, 332 U.S. 174 (1947); Gibson v. United States, 329 U.S. 338 (1946); Eagles v. United States, 329 U.S. 304 (1946).

67. Palmer v. United States, 223 F.2d 893 (3d Cir.), cert. denied, 350 U.S. 873 (1955). This case, Gara v. United States, 178 F.2d 38 (6th Cir. 1949), aff'd by ar equally divided Court, 340 U.S. 857 (1950), and Warren v. United States, 177 F.2d 596 (10th Cir. 1949), cert. denied, 338 U.S. 947 (1950), are most astounding cases. Admittedly sincere religious objectors were convicted in two instances for speech and in one for failing to fill out a form which the draft board could have done itself. It is doubtful, if religious conscience had been protected, that the state would have been incommoded.

68. 98 U.S. 145 (1878). 
lief? To permit this would be to make the professed doctrines of religious belief superior to the law of the land, and in effect to permit every citizen to become a law unto himself. Government could exist only in name under such circumstances." ${ }^{9}$

Almost without exception constitutional law writers assert that "freedom of religion is not an absolute" and is "subject to reasonable exercise of the police power." They do not otherwise face the Reynolds issue.

It might be possible to distinguish Reynolds so as to leave substantial protection in the first amendment for acts of conscience. Thus it may be noted that polygamy, wife burning, human sacrifice and religious murder, which the Court groups together, (1) are all affirmative acts, i.e., the person is trying to do an act contrary to statute, (2) all result in harm to a specific person other than the state, (3) all would be contrary to the basic Judeo-Christian culture of our society, and (4) all involve matters of marriage, divorce and murder, which have always been considered by religion as subject to state regulation. The Court in Reynolds employed the first ground in distinguishing Regina $v$. Wagstaff, ${ }^{70}$ where religious belief was a defense to manslaughter for not feeding a child, on the ground that the Wagstaff offense was inaction, rather than positive action as in Reynolds. The second distinction was used in the flag salute case and the third in the later Mormon cases.

But these distinctions are not satisfactory. Here I must take my stand. The Reynolds case is wrong. We may grant, as it states, that religious freedom is not absolute, for it is hardly possible or desirable at this date to view any provision of the Constitution as absolute in the sense of negating other parts of the Constitution. But neither can we adopt the absolute concept that religion is no defense to a criminal law, as courts and writers tend to imply. We have already pointed to a considerable number of Supreme Court cases in which state statutes or local ordinances were held invalid so far as they prevented a free exercise of religion in holding meetings, ${ }^{71}$ distributing pamphlets, ${ }^{72}$ door-to-door evangelism, ${ }^{73}$ choice of sectarian schools, ${ }^{74}$ refusal to

69. 98 U.S. at 164-67. See also Cleveland v. United States, 329 U.S. 14 (1946); Church of Latter-Day Saints v. United States, 136 U.S. 1 (1890); Davis v. Beason, 133 U.S. 333 (1890); Bartholomew, Polygamous Marriages, 15 ModerN L. Rev. 35 (1952).

70. 10 Cox Crim. Cas. 530 (1868).

71. Kunz v. New York, 340 U.S. 290 (1951).

72. Lovell v. Griffen, 303 U.S. 444 (1938).

73. Saia v. New York, 334 U.S. 558 (1950).

74. Pierce v. Society of Sisters, 268 U.S. 510 (1925). 
salute the flag, ${ }^{75}$ criticism of the war in most intemperate terms, ${ }^{76}$ and similar activity. These cases were decided by reading some religious freedom into the fourteenth amendment due process concept after the Supreme Court had rejected the argument that the original Bill of Rights was carried to all citizens by the privileges and immunities clause. ${ }^{77}$ The due process concept is necessarily relative, defined as what is recognized by the "law of the land." By comparison the first amendment protection of religious liberty is relatively absolute. The words of the first amendment unquestionably are absolute, that "Congress shall make no law . . prohibiting the free exercise [of religion]." But so also are the words as to free speech, press and assembly-unless one wants to indulge in such highly semantic practices as (a) distinguishing between the words "respecting," "prohibiting" and "abridging" used in the amendment, or (b) considering "free exercise" as specifically authorizing action, compared to "freedom of speech" or "right to assemble" as embodying restricted concepts already defined by common law. It seems enough if we recognize that all rights guaranteed by the Bill of Rights are not absolute, but that as to those in the first amendment the prohibitions are in more absolute terms than in concepts such as "due process," and therefore religious liberty should be more fully protected against the federal government than against the states, whereas the reverse seems to occur in practice.

Now I return to my position that the polygamy case is wrong and suggest a way to resolve our. dilemma, a way touched on in some of the Mormon cases. Ours is a constitutional society; the Constitution defines the kind of society we seek to maintain. The word "religion" used in the first amendment had a meaning, and that was what the amendment aimed to protect, fully. It included all branches of Christianity. But it embraced more. It included the great systems of religion recognized by civilization. It did not include the forerunners of religion, often referred to as primitive or barbaric. The distinction is well recognized by all authorities in the field. ${ }^{78}$ The United States as a civilized state did not attempt to protect the barbaric which would deny its very civilization. It established itself as a liberal state believing that it would be enriched if it insured freedom for the living faiths of civilization. It may be this is what the Supreme Court was trying to say in one of the Mormon cases: "The organization of a community

75. Taylor v. Mississippi, 319 U.S. 583 (1943).

76. Gilbert v. Minnesota, 254 U.S. 325 (1920).

77. Hague v. CIO, 307 U.S. 496 (1939) ; Twining v. New Jersey, 211 U.S. 78 (1908); The Slaughter House Cases, 83 U.S. (16 Wall.) 36 (1872).

78. See, e.g., BurTt, MAN SeErs the Divine pt. 1 (1957). 
for the spread and practice of polygamy is, in a measure, a return to barbarism. It is contrary to the spirit of Christianity and of the civilization which Christianity has produced in the Western world."79 But, herein is coupled with a sound reason (that "religion," not "barbarism" is protected) the Reynolds error (that polygamy as such is a return to barbarism). In 1878 the Supreme Court's knowledge of great religions which authorize polygamy, or its sympathy for other religions, may have been inadequate to recognize the necessity for protecting these religions. Or it might have been trying to say that polygamy had not been sanctioned by the Judeo-Christian religion since its pre-civilized or barbaric antecedents and that Mormons could not hide under the cloak of "Christian" a non-religious or barbaric practice. England condemned polygamy at almost the same date, but has since recognized plural marriages under some circumstances, though it has no constitutional protection against parliamentary action. ${ }^{80}$ Today we have sizable Moslem, Hindu, and Buddhist populations in the United States. Diplomats, workers at the United Nations, students in our colleges adhere to those religions. But polygamy is fast disappearing even under such religions as sanction it. I believe that America could have afforded to tolerate religious polygamy until the culture gradually dried it up. The damage to religious freedom in the first amendment and the brutal tearing apart of polygamous families has been a very high price to pay for our "morality." ${ }^{81}$ The above discussion is deemed consonant with the constitutional and cultural history

79. Church of the Latter-Day Saints v. United States, 136 U.S. 1, 49 (1890). Nowhere has the theory been stated more concisely than in State v. Woodruff, 153 Fla. 84, 13 So. 2d 704 (1943), in distinguishing the Mormon cases: "Every system of law rests on a corresponding system of ethics that directs its course. The last-cited cases point this precept. We are committed to a free exercise of religious opinion but since our system of law rests on Christian ethics one would not be permitted to set up a harem and practice polygamy in Florida under the guise of religious freedom because polygamy is contrary to approved moral standards. If our law were predicated on Mohammedan ethics, the converse would be true. If it were predicated on pagan ethics I could sell my child as a slave and if predicated on still another system and I belonged to the sect known as Dukhoborrs, I would be permitted to traverse the highways nude under the guise of religion, but not so in our country because our system of moral teaching raises a different standard that the laze must conform to... A liberated conscience is as essential to a robust democracy as blood is to the human body. Enslave the conscience and democracy will perish as certainly as the body will perish when the blood ceases to circulate. . . . Freedom of conscience is much older than the Declaration of Rights or the common law. Peter and John first invoked it when they were commanded by the high priest and the Roman rulers to speak and teach no more in the name of God.... So the soil from which it springs like many other cherished precepts of the common law reach back to Hebrew origin and historically reveal why a free press, speech, and religion are in a preferred class, protected by the State and Federal Constitutions and immunized from charge by the State." Id. at 87, 88, 13 So. $2 \mathrm{~d}$ at 705, 706.

80. Morris, The Recognition of Polygamoüs Marriages in English Law, 66 HaRv. L. REV. 961 (1953).

81. In re Black, 3 Utah 2d 315, 346, 283 P.2d 887, 908 (1955). 
of our nation, often referred to in determining the meaning of the Bill of Rights.

It is suggested that we stop implying that religious liberty is only for Christians, that belief in a Divine Being is required, and start protecting action taken in conformity with civilized religion. Specifically, that we begin to protect the right of love and conscience against the State, as the highest precept of all high religion.

This should dispose of another Court statement contributing to the subjection of conscience to criminal law: ". . . [that the first] amendment embraces two concepts,--freedom to believe and freedom to act. The first is absolute but, in the nature of things, the second cannot be." 82 Every great religion is not merely a matter of belief; it is a way of life; it is action. The preferred definition of "religion" given by Webster's New International Dictionary is: "The outward act or form by which men indicate their recognition of the existence of a God or gods having power over their destiny, to whom obedience, service and honor are due." (Emphasis added.) And the second definition is: "The feeling or expression of love, fear, or awe of some superhuman and overruling power . . . by the conduct of life." (Emphasis added.) One of the most scathing rebukes in religion is reserved for hypocrites who believe but fail to so act- and the Court has itself defined religion as action..$^{83}$ The first amendment does not use the word "belief." It protects action or "free exercise."

How then shall we weigh the interests involved in the protection of conscience and the resultant conflict with legitimate state aims? We should not underestimate the difficulty of balancing interests in this sensitive area. The Supreme Court has recognized the importance of conscience as so great that "throughout the ages, men have suffered death rather than subordinate their allegiance to God to the authority of the State," that "the First Amendment is the product of that struggle," and that there is "traditionally high respect [for] . . . religious dissent." 84 It has referred to these freedoms as "the chief distinctions that set us apart from totalitarian regimes." 85 On the other hand, it has also labeled the raising of an army as "vital" but flag

82. Cantwell v. Connecticut, 310 U.S. 296, 303-04 (1940); United States v. Ballard, 322 U.S. 78, 86 (1944). A much earlier expression was Reynolds v. United States, 98 U.S. 145, 164 (1878). Some trace this back to Jefferson's Virginia Statute for Establishing Religious Freedom (1786) : “. . . it is time enough ... to interfere when principles break out into overt acts against peace and good order" and his Danbury Baptist (Wall of Separation) letter that the government can "reach actions only, and not opinions."

83. Church of the Holy Trinity v. United States, 143 U.S. 457 (1892); Watson v. Jones, 80 U.S. (13 Wall.) 679,728 (1871).

84. United States v. Nugent, 346 U.S. 1,12 (1953).

85. Terminiello v. Chicago, 337 U.S. 1, 4 (1949). 
saluting as "relatively trivial," 86 and the "right of revolution" as something "no government can recognize" but "change by non-violent constitutional process" as "the basic premise of our political system." 87 Even the most ardent protectors of civil rights avoid anarchy, for "no well-ordered society can leave to the individuals an absolute right to make final decisions," 88 but fear "silence coerced by law" as "the argument of force in its worst form." 89

Regardless of the semantic test used by the Court in deciding particular cases, the following interests in freedom of conscience should be kept firmly in mind:

1) To keep religious belief "absolute," conscience and most actions based on conscience must be kept free.

The Supreme Court recognized in Cantwell v. Connecticut ${ }^{90}$ and elsewhere that religious belief is absolute. For those whose religion is based on internal guidance from God, conscience is the very method of developing belief. To all who fear the term "hypocrite" and remember Jesus' test: "not every man that says, Lord, shall enter the kingdom of heaven, but he who doeth the works of my Father," some freedom for action must be demanded. Beliefs unpracticed atrophy.

2) To avoid civilization's downfall conscience must be strengthened.

Pacifists early diagnosed the illness of civilization as loss of moral integrity or conscience, as have Toynbee, Sorokin and others. They agree entirely with the analysis of Lord John Morley that the most important task is to keep conscience vigorous:

"The immediate cause of the decline of a society in the order of morals is a decline in the quality of its conscience, a deadening of its moral sensitiveness. . . The Greeks became corrupt and enfeebled, not for lack of ethical science, but through the decay in the numbers of those who were actually alive to the reality and force of ethical obligations. . . . Every act of coercion against an opinion or a way of living is in so far calculated to lessen the

86. Board of Educ. v. Barnette, 319 U.S. 624, 638 (1943).

87. Frankfurter, J. in Dennis v. United States, 341 U.S. 494 (1951). 643 (1943).

88. Justices Black and Douglas in Board of Educ. v. Barnette, 319 U.S. 624,

89. Justices Holmes and Brandeis in Whitney v. California, 274 U.S. 357, 375, 376 (1927).

90. 310 U.S. 296 (1940). 
quantity of conscience in the society where such acts are practiced." $\theta_{1}$

3) The state must be furnished a conscience.

The openness of law violations and the punishments undergone for conscience's sake dispel any idea that conscience acts from cowardice or self-interest. These actions are based on a larger principle that lies behind the action. It assumes that a society, like individuals, must be moral. Morality depends on an active conscience. The conscientious actor or objector is seeking to furnish a societal conscience. The state cannot coerce such a man to change his view, for he is not defendinghe is attacking, morally. $\mathrm{He}$ is asking the state to sharpen its conscience; he is conducting a non-violent (and he hopes, constitutional) moral revolution..$^{22}$

4) To obey conscience is to be the good citizen.

"We serve our country best by remaining true to our higher loyalty" (God and conscience rather than State). So reads one of the most famous Quaker communications to government, reiterated again and again from 1655 to 1955 . Justice Douglas, Dean Griswold and others have pointed out that it was two Quakers (Lilburne in England and Bradford in America) who established the fifth amendment protections by refusing to testify against conscience; and it was again two Quakers (Penn and Meade) in 1670 in Old Bailey whose intentional -violations of law for conscience is credited with repeal of the Conventical Acts and the establishment of religious freedom in England. ${ }^{93}$

5) Since the structure of law is founded on conscience, that conscience must remain keen.

Criminal responsibility is imposed on the basis that the individual knows the difference between right and wrong. Everywhere "conscience" is defined as "that moral sense in man which dictates to him right and wrong." ${ }^{84}$ How, then, can you depend upon conscience to

91. Moriey, ON CoMpromise: (1901). See the 1945 expression in Life Magazine: "Our sole safeguard against the very real danger of a reversion to barbarism is the kind of morality which compels the individual conscience, be the group right or wrong. The individual conscience against the atomic bomb? Yes. There is no other way."

92. Muste, Non Violence in an Aggressive World (1944). Freeman, Friends, Conscience and Government, Canadian Friend, Aug. 1955.

93. Douglas, An Almanac of Liberty 236 (1954); Griswold, The Fiftr AMENDMENT (1955); Cadbury, Friends and the Law, Friends Intelligencer (1954).

94. Miller v. Miller, 187 Pa. 572, 578, 41 Atl. 277, 280 (1898); Harden v. State, 188 Tenn. 17, 25, 216 S.W.2d 708, 711 (1948) ; State v. Leuch, 198 Wash. 331, 334, 88 P.2d 440, 441 (1939); 6 ENCYCLOPEDIA BRITANNICA 282 (1947): "In either theory, [jural or intuitive] conscience [has] ... two functions of discerning between right and wrong, and actively predisposing the agent to moral action. ...." 
put morality into your criminal law if you are going to make criminals of those who most actively follow conscience? ${ }^{95}$

6) Those with the most active conscience should be encouraged to, rather than excluded from public office.

The Constitution provides that no religious test oath for public office shall be employed. Yet all oaths of office require that a person "defend the Constitution." If conscientious objection is not a constitutional right, and if "defend" is interpreted to mean by force of arms, then all persons conscientiously opposed to war are effectively removed from office by a religious test oath. ${ }^{96}$ It is not mere coincidence that so few Quakers, Brethren, Mennonites and like persons are in American Government and that many more are working for the United Nations.

7) In the world battle for men's minds America must demonstrate vital democracy and liberty.

"The secret of liberty is always, in the end, the courage to resist." 97 And a vital democracy is always composed of "courageous, self-reliant men" who do "not exalt order at the cost of liberty." 88 We may have taken chances of serious social upheaval in the Brown desegregation case ${ }^{99}$ but it was essential to winning the minds of colored men all over the world. Does our failure to protect conscience stand in the way with nations grounded in Buddhism, Hinduism and like faiths?

Conscience has presented its case not merely in terms of its own interest, but as involving points at which the individual and the governmental interest coincide. But government has other real interests which seem antagonistic to conscience. It has been given the power to preserve itself and wage war. It must support itself by taxes and cannot tolerate extensive anarchy. It should follow the doctrine of equality for all citizens and not create preferences. It must thwart licentiousness, criminality and fraud, and encourage morality and responsibility. We believe that all these interests can be best served, in fact, may only be served by a protection of sincere conscience.

We began this study with the Dutch grant of a right of "conscience" in New York in 1657, and its decision upholding Bowne's

95. $C f$. cases cited in note 65 supra.

96. See United States v. MacIntosh, 283 U.S. 605 (1930).

97. LASKr, LibERTY IN THE MODERN STATE 80 (1930).

98. See note 89 supra.

99. Brown v. Board of Educ., 347 U.S. 483 (1954). 
refusal to obey a colonial law which violated his religious conscience. It is fitting that we conclude with the case of Matter of Fethus van Lieshout, decided 300 years later. Holland has no free exercise of religion constitutional requirement, but it accepted Lieshout's defense of obedience to conscience as excusing his refusal of military service:

"The accused must be considered as having committed the act accepted above as proved, driven thereto by force majeure [God] . . . and therefore not punishable and should be acquitted of that which he is charged." 100

Three hundred years ago William Penn said of Holland in Persuásive to Moderation: "Holland cherished her people . . . and by making them easy in the main point, their conscience, she became great by them."

Can America today protect its citizens in "their conscience" and thereby "become great"?

100. Peace News, March 11, 1949. 